\title{
KĀ BŪTU, JA NEBŪTU...
}

\author{
Ginta Apala un Māra Zandera polemiskās sarunas \\ Latvieši, vācbaltieši un Krievija izraisitās pārdomas
}

Pēteris Bolšaitis, studentu korporācijas Fraternitas Lettica filistrs

Manuprāt, kaut kas tāds kā "objektīva vēsture" nav iespējams. Katrs cilvēks, katra kopiena, katra tauta uz vēsturiskiem notikumiem raugās no sava skatpunkta, un, kā mēs to piedzīvojam arī mūsdienās, vēsturi pat var pārrakstìt, lai tā kalpo kādam politiskam mērķim. Džordžs Orvels (George Orwell) savā grāmatā 1984 formulēja trāpīgo aforismu: "Tas, kurš kontrolē pagātni, kontrolē arī nākotni.” Ne mazāk nozīmīgs šìm pārdomām ir otra Džordža - Santajanas (Santayana) - aforisms: "Kas nemācās no pagātnes kḷūiām, tam nāksies tās atkārtot."

Ginta Apala un Māra Zandera "polemiskā saruna” grāmatā Latvieši, vācbaltieši un Krievija (2020, Rīga: Aminori) skaudri atsaucas uz iepriekš minētajām gudrībām. İpaši tādēl, ka mūsu tautas vēsture ir tik šķautņaina un skatītājam no malas grūti saprotama. Klāt vēl būtu jāievēro, ka autori pievēršas ne tikai iespējamām mūsu pagātnes kḷūdām, - bet aizmirstai vēsturei vispār. Mankurtismam! Kad pēc ilgiem gadiem trimdā atgriezos Latvijā, kādā sarunā ar augstāko izglitību guvušu personu nācās pieminēt vācbaltiešus. "Jā," viṇa atsaucās, "esmu dzirdējusi, ka tādi te esot bijuši." Tik daudz par septiņu gadsimtu vēsturi, kas vairums rakstìta vācu valodā, kurā tikai retais latvietis vairs prot lasit.

Lìdzīgs pārsteigums man bija, kad, apṇēmies pārtulkot netālu no Smiltenes dzimušā Zigfrīda fon Fēgezaka (Siegfried von Vegesack) monumentālos vēsturiskos romānus Senči un pēcteči (Vorfahren und Nachkommen) un Baltiešu gredzens (Baltische Tragödie un Der Letzte $A k t)$, nevarēju atrast nevienu vēsturnieku vai literātu, kurš par autoru un viṇa darbiem būtu ko dzirdējis. Kad šo projektu piedāvāju izdevniecībai Jumava, saņēmu atbildi, ka "šis temats mūsu lasītājiem neinteresē". Šo stāstu nevis tāpēc, lai kādam ko pārmestu (šīs grāmatas ir pārtulkotas, izdotas, guvušas lielu atzinību un plašu lasītāju loku), bet gan lai parādītu, kā "uzvarētāji" raksta vēsturi un spēj ietekmēt nākotni. Pēdējos gados ir iznākušas daudzas grāmatas, kas aizpilda izdzēstās vēstures lappuses. G. Apala un M. Zandera grāmata ir vēl viena artava šim pasākumam.

Mūsu vēsture ir savāda un tragiska. Ne jau tādēḷ, ka mūsu zemi iekaroja un kolonizēja cita tauta, - tāds liktenis bijis lielam vairumam pasaules tautu, bet gan tādēḷ, ka mūs kolonizēja divas (ja neskaita dažas citas, kas to darīja uz īsāku laiku) lielvalstis, kas mūs pārmijus "apspieda" un "atbrīvoja" viena no otras. Dīvainā kārtā šis apstāklis mums, iespējams, palīdzēja izaugt par īpašu, ar savu raksturu apveltitu tautu$^{1}$. Bez Krievijas mēs būtu varējuši kḷūt par Lielvācijas provinci ar pārvāciskotu pamattautu. Sliktākā gadījumā mums būtu bijis lemts senprūšu liktenis. Bet, ja nebūtu bijis vācbaltiešu, mēs šodien līdzinātos baltkrieviem vai arī jau 1919. gadā būtu kḷuvuši par pirmo padomju republiku un vēlāko Padomju Savienības sastāvdaḷu. Tā ka nav l̦aunuma bez sava labuma.

G. Apala un M. Zandera polemiskā saruna izraisa daudz pārdomu, ar kurām varētu pierakstīt simtkārt biezāku grāmatu, bet pamatjautājums varētu būt: kādēl pret vieniem mūsu kolonizētājiem, no kuriem mēs esam ieguvuši savu piederību Rietumu civilizācijai, vēsturiski

\footnotetext{
${ }^{1}$ Sal. Tāgepera, Reins (2010) Alberts, Mārtiņš un arī Pēteris: viṇu loma latviešu un igauņu nāciju izveidē. Akadèmiskā Dzīve, 49, 3-12 - red.
} 
esam jutuši tik žultainu naidu, kamēr no otra bija jāsagaida stal̦inisma terors, lai rastos salīdzināma antipātija. Neaizmirsīsim, ka Kārlis Ulmanis īsi pēc tam, kad pēdējiem vācbaltu aizbraucējiem bija pateicis "Uz neredzēšanos!", aicināja tautu palikt savās vietās brīdī, kad aizbraucējus atvietot ienāca Austrumu civilizācijas l̦audis no "mums draudzīgas valsts".

Manuprāt, no tīri cilvēciskā viedokḷa šo un daudz citu muļ̣īibu un l̦aunumu, kas notikuši un notiek pasaulē, izskaidro viens no lielākajiem grēkiem: mantrausība (jeb alkatība), kas reizē ar varaskāri iedvesmo vardarbību, slepkavības, revolūcijas un karus. Mūsu plašo, vērtīgo, no vācbaltiešiem gūto mantojumu - kas sniedzas no Minox fotoaparāta lìdz dziesmu svētku tradīcijai - apēnoja nedaudzi mantas un varaskāri muižnieki. Viņus savukārt tikpat mantas un varaskāri pretinieki izmantoja, lai nomelnotu un no tautas atmiņas dzēstu muižniecības vērtīgāko daļu. G. Apals pareizi norāda uz šo faktu, bet savā ìsajā polemikā varbūt pietiekami neiedziḷinās šîs rīcības graujošajās sekās. Tāpat derētu pievērst lielāku vērību tiem nedaudzajiem vācbaltiešiem un latviešiem, kuri 19. gs. otrajā pusē izmisīgi cīnījās pret konservatīvās bruṇniecības koloniālismu un Jaunās strāvas iedvesmoto boḷševismu. Šādā ziņā interesanta ir nesen latviešu valodas tulkojumā iznākusī Ernsta fon Menzenkampfa (Ernst von Mensenkampff) grāmata Cilvēki un likteñi senajā Lìvzemē. Autors apraksta ne tikai lielo spriedzi, kas pastāvēja vācbaltiešu muižniecības un tā saucamo "literātu" starpā (viṇa tēvs bija muižnieks, bet māte "literātiem" piederīga), bet sīki un dokumentēti apraksta arī sīvo cīnu par saimnieciskām un politiskām reformām, ko saujiṇa gaišredzīgu landtāga (faktiski Vidzemes provinces parlamenta red.) locekḷu veda pret saviem arvien reakcionārākajiem kolēgiem. Tāpat derētu izcelt l̦oti vērienīgo vācbaltiešu līdzdalību Latvijas valsts politikā tās ìsajā demokrātijas laikā Paula Šìmaņa vadībā. Viņš tika ievēlēts visos Saeimas sasaukumos, pārstāvēja Latviju Tautu savien̄̄bā un reiz arī tika aicināts kḷūt par premjerministru!

Šādā sakarā ir interesanti lasìt šis "valdošās škiras” raksturojumu, ko mums sniedzis Z. fon Fēgezaks savās ğimenes un personīgās vēstures grāmatās. Cita starpā viṇš stāsta par saviem
Tērbatas Universitātes studiju biedriem, muižnieku dēliem, kurus citi dēvēja par "bruņniecības ērzeliiem”. Tērbatā tie bija ieradušies galvenokārt, lai gūtu "krāsas" studentu korporācijās, "žūpotu un kautos" (vāc. saufen und raufen). Iemantojuši muižas un atgriezušies mājās, viṇi nodevās medībām, zirgu audzēšanai un reizi gadā devās uz Rīgu landtāgā lemt par valsts jautājumiem, bet vakaros likssmot Romas viesnīcas pagrabā. Tā, mazliet ironizējot, var secināt no Z. Fēgezaka un E. Menzenkampfa savu šķiras biedru aprakstiem. Šādi pusizglītoti, turīgi un reizē vareni cilvēki bieži iekrīt vēl citā grēkā, vēl lielākā pat par mantkārību: augstprātībā.

Bet pretinieki nebija daudz iepriecinošāki. Kārlis Markss savā Komunistiskās partijas manifestā bija deklarējis (vāc.): "Der Arbeiter hat kein Vaterland." Tātad strādniekam jeb "proletārietim" nav tēvzemes. Liela patiesība, kas izskaidro daudzus tālaika notikumus. Ne jau birztalas un dainas iedvesmo patriotismu, bet gan savs īpašums, gimene, ražīgs darbs un sabiedrība. Nozīmīgs ir fakts, ka latvieši labprāt devās prom no dzimtenes, ja viniiem kaut kur tālumā - Krievijā, Brazīlijā - piedāvāja zemi.

$\mathrm{Uz}$ to visai trāpīgi norāda G. Apals. Es citēju (52. lpp.): Pärkrievošanās perspektīva nebija nekāds bieds. To skaidri postulējis jau bija Valdemārs, paužot uzskatu, ka, krieviski runādami, latvieši, kā daudzi jau zinās, nekad nezūd tautai, arì tad ne, kad tie, pa daļai, jau sāk aizmirst latviski runāt. Lielais "latvietis" Krišjānis Valdemārs?!

Bet par Andrievu Niedru un Frīdrihu Veinbergu viņš raksta: Niedra bija mācìtājs, blakus nacionāliem mērķiem viñam bija arī ètiskie imperatīvi. To skaitā doma, ka labklāj̄̄ba jāsasniedz ar darbu, nevis revolucionāru ekspropriāciju. Kā arī ideja, ka nacionālai identitātei vajadzīgs ètisks kodols, savstarpēja solidaritāte un emocionāla kopības sajūta. Konservatìvu vīziju par latviešu tautas attīstību pārstāvēja Frīdrihs Veinbergs un viña domubiedri, kas uzskatīja par nepieciešamu veidot latviešu augšslāni, kas varētu politiski pārstāvēt latviešu tautu tradicionālajā kārtu sabiedrībā, sadarbojoties ar Baltijas muižniecību.

Pēc 1905. gada revolūcijas īsu brīdi valdīja pulcēšanās brīvība. Uz pirmo latviešu skolotāju kongresu, kas 1905. gada 10. novembrī 
norisinājās teātra namā Romanovu (Lāčplēša) ielā 25, bija ieradušies daudzi žurnālisti un zinātnieki. Arī Rainis un Aspazija. Tātad ne gluži tradicionālais "proletariāts". A. Niedra lūdza vārdu, un tas viņam tika dots. Bet, kad viņš izpauda savus ètiskos iebildumus pret revolūcijas rīcībām un mērḳiem, viṇu izsvilpa un gandrīz nolinčoja. Vēlāk, jau neatkarības laikā, viņu notiesāja kā "valsts nodevēju" un izraidija no Latvijas.

F. Veinbergs, kā man stāstījusi viṇa meita Elizabete, bijis liels anglofils un pie savas gultas ikvakara lasišanai turējis Džona Ričarda Grīna (John Richard Green) angḷu tautas vēstures grāmatu The History of the English People. Būdams pārliecināts monarhists un pirmais latviešu jurists ar kandidāta grādu no Maskavas Universitātes, viņš nikni (bet ne mudinot uz dedzināšanu un slepkavošanu) cīnījās pret vācbaltiešu valdošo slāni. Viṇa mērḳis bija autonoma, latviešu pārvaldìta province parlamentāras Krievijas impērijas sastāvā. Kad izcēlās 1905. gada revolūcija, viņš tikpat kā vienīgais no ievērojamiem latviešu politiķiem asi nostājās pret to un izpelnijāa ne tikai izslēgšanu no studentu korporācijas Fraternitas Moscoviensis, kuras goda filistrs (un galvenais finansētājs) viṇš bija, bet arī "melnsimtnieka" un "reakcionāra" apzīmējumu no sociāldemokrātu puses, kas iegūlies latviešu psihē līdz pat mūsdienām.

Bet F. Veinbergs izrādījās arī pragmatikis. 1917. gadā, kad vācu karaspēks ieṇēma teju visu Latvijas un Igaunijas teritoriju un Krievija šḳita karu zaudējusi, viņš iestājās par sadarbību ar vācbaltiešiem Baltijas valsts veidošanā, kas pastāvētu personālūnijā ar Vāciju. Par neatkarīgu Latvijas Republiku tolaik reti kāds domāja. Tikai Miḳelis Valters 1903. gadā ieminējās par tādu iespēju.

Kad beidzot, pateicoties ippašu apstākḷu sakritībai, izdevās proklamēt neatkarīgu Latvijas Republiku, sarkanie strēlnieki - "revolūcijas armija”, ko L̦eṇinam bija piedāvājis Pēteris Stučka, - jau bija ieṇēmuši pusi Latvijas un strauji virzīāàs tālāk. Pirmie, kas pieteicās aizstāvēt Latviju ar ieročiem rokā, bija vācbaltiešu landesvērs - ap 2500 brīvprātīgo, kas atsaucās uz aicinājumu (vāc.): "Die Heimat ist in Gefahr!" (Dzimtenei draud briesmas!). Viñiem piebiedrojās latviešu rezerves virsnieki, zemessargi un saujin̦a latviešu studenti, kopā ap 650 vīru, kas sastādīja Oskara Kalpaka bataljonu. Vēlāk arì ap 18000 vīru stiprā vācu brīvprātīgo Dzelzsdivizija (kuriem Latvijas valdība solīja - bet vēlāk nedeva - zemi kā atlīdzìbu), angḷu un franču karakug̣i, somu jēgeri, dāṇu brīvprātīgie, Anatola Līvena vadītā krievu virsnieku rota, igauņi ar savu bruṇoto vilcienu un poḷi Latgales atbrīvošanā. Lai cik ironiski tas arī neskanētu, ar daudzu sabiedroto palīdzību Latviju izdevās atbrīvot no 40000 vīru stiprās latviešu sarkanarmijas (strēlniekiem). Bet šie cittautieši, kas nāca palīgā, cīnījās ne jau par brīvu Latviju, bet gan pret draudošo boḷševismu. Savukārt boḷševiki - par Latvijas Sociālistisko Padomju Republiku. Un tomēr...

G. Apals aizrāda, ka pirms Pirmā pasaules kara kā latvieši, tā vācbaltieši meklēja savu interešu aizstāvību pie cara valdības. To varētu attiecināt uz latviešu pilsoniskajām aprindām - K. Valdemāru, F. Veinbergu, Andreju Krastkalnu un vai visiem Rīgas Latviešu biedrības runasvīriem. Bet nedrīkst aizmirst, ka tieši sociāldemokrāti, vēlāk pa daḷai pārtapuši par boḷševikiem, spēlēja izšķirošu lomu mūsu valsts tapšanā.

Pirms daudziem gadiem, kad es vēl dzivoju Venecuēlā (Venezuela latviski rakstìta pēc vācu izrunas), man gadījās iepazìt turienes Komunistiskās partijas dibinātāju un vadoni Gustavo Mačado (Machado), kurš savos jaunibas gados bija devies uz Krieviju piedalîties revolūcijā. G. Mačado uzskatija sevi par pēdējo dzīvo cilvēku, kas personīgi kalpojis L,en,inam. Kad mani ar vinu iepazīstināja, sirmais kungs mani sirsnīgi apkampa un teica: "Es noprotu, ka tu esi latvietis, un katrs latvietis ir mans draugs, jo biedrs L̦eņins allaž atgādināja, ka, tikai pateicoties latviešiem, mēs uzvarējām." Šo īpašo attieksmi L̦eņina un latviešu starpā visos sīkumos aprakstījis Roalds Dobrovenskis grāmatā Rainis un viņa brāļi. Līdzīgu "atzinumu", bet, pateiktu citā balss tonī, man nācās dzirdēt no draugiem, krievu emigrantiem - senais stāsts par žīdu smadzenēm, latviešu dūrēm un krievu muļ̧̣ibu. Arī mēs paši esam lepni uz saviem strēlniekiem, kas trīs sarkanos tēlos iemūžināti Latviešu strēlnieku laukumā Rīgā, un bieži atsaucamies uz viṇiem kā Latvijas neatkarības cinnu varoṇiem.

Bet L,eñinam nenoliedzami bija taisnība. Mērķu sasniegšanai viņam līdzēja ne tikai 
"revolūcijas armija”, bet arī cītīgi latvieši, kā Pēteris Stučka - Pravdas redaktors, pirmais tieslietu tautas komisārs, Augstākās tiesas priekšsēdētājs un padomju likumu galvenais veidotājs. Citāts no jurista un padomju darbinieka Ernesta Sietiņsona atmiṇām: Laikam gan nevienam no mums toreiz nebija juridiskās izglìtības. Un te mums ḷoti noderēja P. Stučkas sastādìtie Padomju valdības dekrēti Par tiesu un revolucionārajiem tribunāliem, $k \bar{a}$ arī Tieslietu tautas komisāra instrukcijas. Dekrēta Nr. 1 vadošais princips bija revolucionārā sirdsapziņa un revolucionārā tiesiskā apziña. Par likumīgu bija uzskatāms tas, kas atbilda revolūcijas interesèm. $^{2}$

Ne mazāk svarīgs L̦eņinam un viņa boḷšsevikiem bija Eduards Bērziņš. Kā padomju valdības apsardzes vadītājs viņš L̦eṇinu pasargāja no viena otra atentāta. Vēlāk viņš Magadanā izveidoja pirmo "darba" (resp., koncentrācijas) nometni, kas kḷuva par iedīgli visai Gulaga sistēmai.

Ja varam ticèt Vikipédijai, tad no pirmajiem 70 čekas komisāriem 36 bija latvieši. Jēkabs Peterss un Mārtiņš Lācis bija asiṇainā Edmunda Dzeržinska tuvākie līdzstrādnieki. Arī starp Lubjankas cietuma apsargiem vairums esot bijuši latvieši. Un kur nu vēl slavenais pirmais Sarkanarmijas virspavēlnieks Jukums Vācietis! Viṇš ar saviem strēlniekiem sagrāva katru pretestību bolš̌eviku režìmam.

Bet kas būtu, ja nebūtu? Labs domu eksperiments! Ja boḷševiki nebūtu uzvarējuši, tad gan Krievijā, gan Vācijā pēc kara būtu izveidojušās republikas vai parlamentāras monarhijas. Stal̦ins un Hitlers nebūtu nākuši pie varas, bet Latvijas un Igaunijas neatkarībai diez vai būtu bijis atbalsts Rietumos. Atkarībā no miera ligguma noteikumiem tās būtu varējušas kḷūt par puslīdz autonomām Krievijas provincēm, līdzīgi Katalonijai Spānijas sastāvā, vai arī abas kopā būtu kḷuvušas par Baltijas hercogisti personālūnijā ar Vāciju.

Vienā vai otrā gadījumā viegli iedomāties, ka Igaunija un Latvija būtu kḷuvušas par l,oti turīgām valstīm. Tirdzniecības un finanšu centri starp Krieviju un Rietumiem ar augsti izglìtotu iedzīvotāju kontingentu. Tautas vispārējais dzīves līmenis būtu bijis ḷoti augsts. Protams, darījumi un politika pārsvarā notiktu vācu valodā. Vairums izglìtoto latviešu būtu zinājuši trīs vai četras valodas, un visās skolās būtu jāmāca arī "pamattautas" valoda. Valsts dāsni atbalstìtu "pamattautas" kultūras un tradīciju saglabāšanu, īpaši uz laukiem, un tūristi no visas pasaules plūstu uz Baltiju priecāties par vissenāko eiropiešu krāšņajiem tautastērpiem un skaistajām dziesmām un dejām.

Forši?... Bet vai tomēr labāk nepateikties strēlniekiem?

Vēl vienu "kā būtu" G. Apals izceḷ, pieminot Somijas pieredzi: .. somu tauta saliedējās ar zviedru minoritāti, atrada sadzīvošanas modeli, un karā pret Padomju Savienību to sekmīgi veda vācu izcelsmes zviedru tautības muižnieks, bijušais Krievijas genenealleitnants Karls Mannerheims. Latvijas tautu karā par neatkarības saglabāšanu neveda neviens.

Varētu vēl piebilst, ka K. Mannerheims bija precējies ar krievieti un somiski esot runājis l̦oti vāji.

Bet tā ir monētas viena puse. Otra ir Somijas pilsoṇu karš, kas norisinājās reizē ar cīṇām pret boḷševikiem Latvijā. Arī tajā somu pilsoṇu spēkus kaujā pret sociāldemokrātiem (bet vēl ne boḷševikiem) veda K. Mannerheims. Katrā pusē bija 80 000-90 000 somu. Pilsoņu pusi atbalstīja 14000 vīru stipra vācu armija Rīdigera fon der Golca (Rüdiger von der Goltz) vadībā un saujiņa zviedru, igauṇu un poḷu brīvprātīgie, bet sociāldemokrātu pusi - ap 10000 krievu. ${ }^{3}$ Cinna bija nežèlīga un asinaina, un labējo spēku uzvara graujoša. Ap 10000 kreiso nošāva, vēl ap 12500 gāja bojā gūstekṇu nometnēs no bada un slimībām. Kopā ar kritušajiem apmēram 32500 bojāgājušo salīdzinājumā ar 5700 labējo pusē. Interesanti, ka Vācija arī Somiju centās izveidot par karaḷvalsti personālūnijā ar Vāciju. 1918. gadā no 9. oktobra līdz 14. decembrim Somijā kā karalis valdīja Vācijas k̦eizara svainis, Hesenes princis Kārlis Frīdrihs. Somijas pakḷaušana Vācijas interesēm neizdevās, un Zviedrija jau sen bija atmetusi vēlmi atgūt savu kādreizējo provinci. Toties Vācijas vēlme, dažu vācbaltiešu mudināta,

\footnotetext{
3 Visi dati ņemti no Vikipēdijas.
}

2 No: Dobrovenskis, Roalds (1999) Rainis un vina brāḷi. Rìga : Jumava, 520. 
Baltiju no jauna kolonizēt turpinājās līdz pat Otrajam pasaules karam.

Interesanti, ka pēdējos gados rīkotās aptaujās dažādās pasaules valstīs, lai noskaidrotu, kuras valsts iedzìvotāji ir "vislaimīgākie", par tādiem atzìti somi. Meklējot izskaidrojumu, konstatēts, ka somi savā zemē jūtas laimīgi, jo "esot vienoti un varot cits citam uzticēties". Interesanti, ka tieši tas - vienotība un savstarpēja uzticēšanās - bija A. Niedras ieteikums saviem sadumpotajiem tautiešiem 1917. gada skolotāju kongresā.

Pēc asiņainā pilsoṇu kara Somijā ilgi pastāvējusi saspringtība un šķelšanās. Bet vajadzība savu valsti aizstāvēt brīdī, kad 1939. gada novembrī tai uzbruka Padomju Savienība, tautu atkal apvienoja. Patriotisms pārvarēja politiskas domstarpības. Somi no vēstures ir mācījušies.

Arī mums derētu mācīties no Latvijas sarežğìtās un traǵiskās vēstures. Uz to pamudina arī G. Apala un M. Zandera grāmatas vērtīgais, pārdomas veicinošais saturs.

Piezīme. Lai teikto atbalstītu arī ar darbu, mēs kopā ar prof. Eduardu Andersu esam Vìtolu fondā radijjuši ipašu stipendiju maǵistratūras un doktorantūras studentiem Latvijas 20. gs. vēstures pētījumiem. Mūsu pirmais stipendiāts Andrejs Gusačenko nesen guva 2020. gada vēsturnieka pagodinājumu. Aicinām pieteikties! 